\title{
Verb-Noun Collocations in Written Discourse of Iranian EFL Learners
}

\author{
Fatemeh Ebrahimi-Bazzaz (Corresponding author) \\ Department of English Translation, Islamic Azad University, Tehran North Branch \\ Language College, Bozorograh Shaid Babaei, Hakimieh, Chamanara Street, Tehran 1651153311, Iran \\ E-mail: fatemehebrahimibazzaz@gmail.com \\ Arshad Abd Samad \\ Department of Language Education and Humanities Faculty of Educational studies \\ University Putra Malaysia, 43400 UPM Serdang, Selangor Darul Ehsan, Malaysia \\ E-mail: arshad.samad@yahoo.com \\ Ismi Arif bin Ismail \\ University Putra Malaysia, 43400 UPM Serdang, Selangor Darul Ehsan, Malaysia \\ E-mail: ismilina@gmail.com \\ Nooreen Noordin \\ Department of Language Education and Humanities, Faculty of Educational Studies \\ University Putra Malaysia, 43400 UPM Serdang, Selangor Darul Ehsan, Malaysia \\ E-mail: nooyeen@yahoo.com
}

Received: 15-12- 2014

Published: 01-07- 2015
Accepted: 16-02- 2015

doi:10.7575/aiac.ijalel.v.4n.4p.186
Advance Access Published: February 2015

URL: http://dx.doi.org/10.7575/aiac.ijalel.v.4n.4p.186

\begin{abstract}
When native speakers of English write, they employ both grammatical rules and collocations. Collocations are words that are present in the memory of native speakers as ready-made prefabricated chunks. Non-native speakers who wish to acquire native-like fluency should give appropriate attention to collocations in writing in order not to produce sentences that native speakers may consider odd. The present study tries to explore the use of verb-noun collocations in written discourse of English as foreign language (EFL) among Iranian EFL learners from one academic year to the next in Iran. To measure the use of verb-noun collocations in written discourse, there was a 60-minute task of writing story based on a series of six pictures whereby for each picture, three verb-noun collocations were measured, and nouns were provided to limit the choice of collocations. The results of the statistical analysis of ANOVA for the research question indicated that there was a significant difference in the use of lexical verb-noun collocations in written discourse both between and within the four academic years. The results of a post hoc multiple comparison tests confirmed that the means are significantly different between the first year and the third and fourth years, between the second and the fourth, and between the third and the fourth academic year which indicate substantial development in verb-noun collocation proficiency. The vital implication is that the learners could use verb-noun collocations in productive skill of writing.
\end{abstract}

Keywords: Language proficiency, Verb-noun collocation, Witten discourse, Iranian EFL learners

\section{Introduction}

According to Miyakoshi (2009), there are three main kinds of views on the work on collocations: (1) corpus research views, (2) sentence- and discourse-building views, and (3) linguistic views. In corpus-based research collocations have been discussed by Aijmer, Altenberg, and Svartvik (1991), Benson, Benson, and IIson (1997), Kennedy (1990), Kjellmer (1991), Liao (2010), and Sinclair (1991). In his corpus research on collocations, Kjellmer (1991) defines collocations as such sequences of items as are grammatically well formed. This definition adapts a broad interpretation of the term, giving the name to all greater-than-chance groups of words that are grammatically well-formed. Benson, et al., (1997) and Kjellmer (1991) adapt a practical operational approach which reflects the procedure they use to extract collocations from language corpora data and study them (cited in Miyakoshi, 2009, p. 1).

In the sentence- and discourse-building view, Nattinger and DeCarrico (1992) examined both the psychological and the distributional phenomena of language. They suggest that lexical phrases are extremely common in fluent speech and writing, and that they are an important source of linguistic material for language learners to analyse and to derive syntactic and lexical information.

In the linguistic view, the term collocation is reserved for a specific, quite linguistic phenomenon. Wood (2010), for example, considering the native speakers' entire repertoire of utterances, proposes a cline of language from productivity to frozenness. He considers semantic compositionality and productivity of form for phrases as factors that constitute a continuum from complete frozenness to full freedom of combination. While these three views related to collocations seem to have their advantages, it is not significant which view is better. Nevertheless, knowing these views and their 
applications help us to understand the nature of collocations, and how they can be studied in order to aid EFL learners in mastering them. In this study, I implement Lewis's idea that: "A collocation is two or more words that tend to occur together" (Lewis, 2000, p. 73) as his definition is appropriately explains the phenomenon which I am studying. Collocations are the co-occurrences of words and have syntagmatic relations which are predictable to some extent.

Firth (1957a) gave "collocation" its theoretical prominence, and in a later work (Firth, 1968), defines "collocations as statements of habitual or customary places of that word" (p. 181). Furthermore, Krishnamurthy and Kosem (2007) notes that Firth separated collocations from cognitive and semantic idea of word meaning and words obtain their meaning from their co-occurrence in texts. Following the same line of research as Firth (1968), Cruse (1986) proposes that collocations are a "sequence of lexical items which habitually co-occur" (p. 40). Nattinger and DeCarrico (1992) added more to the notion that a collocation unit includes a "node" that co-occurs with a "span" of words on either side. They define collocations as "strings of specific lexical items, such as rancid butter and curry favour that co-occur with a mutual expectancy greater than chance" (p. 36). They regard lexical phrases, such as how are you, as collocations with pragmatic functions.

However, another explanation about collocations is presented by Lewis (1997a, 2010) who indicates collocations are the lexical items that co-occur naturally with deliberate frequency and usually are prefabricated. Yet, Carter (1998) argues that collocations are a group of words that recurrently appear in a language. "These patterns of co-occurrence can be grammatical in that they result primarily from syntactic dependencies or they can be lexical in that their relationship is lexical, although syntactic relationships are involved" (p. 51). In addition, Nation (2001) states that collocations are "closely structured groups whose parts frequently or uniquely occur together and have some elements of grammatical or lexical unpredictability or inflexibility" (p. 324).

This research merely studied the verb-noun collocations. Although it is the most frequent form of collocation, as asserted by Bensen, et al. (1986) and has been investigated by other researchers like Aghaber (1990), Bahns and Eldaw (1993), Biskup (1992), Al-Zahrani (1998), Hsu and Chui (2008), and Bagherzadeh Hosseini and Akbarian (2007), competence in this collocation form may not inevitably show a learners' overall collocational knowledge. Nevertheless, it is the focus of this study because of the frequency of verbs and nouns in everyday language.

\section{Written Discourse}

Discourse refers to a vast area of human life; therefore, only discourse from the vantage point of linguistics, and especially applied linguistics, is explained here. It is conceptualised as "an on-going stretch of language bigger than a sentence, and it often constitutes a coherent unit like a sermon, argument, joke, or narrative" (Crystal, 1992, p.25). "Written discourse refers to non-reciprocal and production types of discourse in which the writer does not know the reader. It is usually well planned and has coherent sentences (Crystal, 1992, p. 291)." In other words, language used for communication is labelled as discourse that has been constructed as the consequence of an act of communication.

Nattinger (1980) also designates that it is both fairly easier to keep and memorise a new word in a network of associations, and language chunks to help learners to remember information. Especially, Collocations are useful in improving comprehension for the association of words, contribute the learners in storing words in memory, and allow individuals to remember which words come together. In contrast, collocations are useful for teaching language production since students observe certain lexical restrictions use by memorising collocations as well. For instance, if students know collocations such as a convenient situation and a convenient time but not *a convenient person, they will realise subconsciously that the adjective convenient is merely employed with inanimate nouns. Students do not recreate the language whenever they wish to utter something, however, instead can manipulate these collocations as "prepackaged building blocks", and ultimately, collocations will move learners' attention from single words to the larger structure of the discourse.

Many researchers discussed the relationship between collocations and the productive language, especially writing (AlZahrani, 1998; Bazzaz and Samad 2011; Farghal \& Al-Hamly, 2007; Hsu, 2002; Zhang, 1993). Zhang (1993) was the first to study the correlation between knowledge and the use of collocations and the quality of collocations in 30 native and 30 non-native Indiana University of Pennsylvania freshmen .Al-Zahrani's study did not follow Zhang's because AlZahrani did not consider the use of collocations. Therefore, he made no report about his subjects' frequency of collocations in the Writing Test. Al-Zahrani's study investigates the correlation between Saudi EFL students' knowledge of lexical collocations and their general proficiency in English and their academic levels. He suggests teachers should incorporate a large amount of collocations with special emphasis on collocations that do not have linguistic and cultural equivalence in the native language. Another suggestion which was given was that EFL teachers should encourage their students to use English collocational dictionaries, such as The BBI Dictionary of English Word Combinations. He concludes that even though Saudi EFL students' knowledge of lexical collocation develops along with their general language proficiency, learners still will benefit from intense instruction of collocations.

On the production of collocations in written discourse, Farghal and Al-Hamly (2007) performed a study on collocations as a challenging feature of foreign language learning and as an integral component of communicative competence. They observed lexical collocations in Kuwait University EFL learners' essay writing. The learner database included one hundred essays written as final examinations for ENG 208 (Essay Writing). Collocational errors were first inspected in terms of head type and collocator vs. collocate orientation. Subsequently, collocations were argued in light of their etiology, i.e. whether they were the output of L1 interference or creative construction. The researchers indicated that the majority of KU prospective English majors experienced a range of mild to serious problems in the area of lexical collocations, among other things. They conclude that the ability to utilise natural collocations in foreign language compositions can be taken as an indicator of workable competence in writing, but they did not concentrate on the spoken discourse of learners. 
The goal of this study is to find the use of verb-noun collocations in written discourse of EFL learners in Iran. I hope that the study may contribute to a better understanding about the role of verb-noun collocation instruction in the development and enhancement of written discourse in EFL situations.

\section{The present study}

The present study is part of my $\mathrm{PhD}$ thesis, first, the relationship between language proficiency and collocational competence was calculated. The results of the statistical analyses demonstrate that there is a high positive relationship between collocational competence and general language proficiency of learners (Ebrahimi-Bazzaz, Samad, Ismi, and Nooreen, 2012). Second, the relationship between verb-noun collocation proficiency and academic years was estimated. The results of ANOVA exhibited there was variability in the verb-noun collocations proficiency within each academic year and between the four academic years. The results of a post hoc multiple comparison tests proved that the means are significantly different between the first year and the third and fourth years, and between the third and the fourth academic year (Ebrahimi-Bazzaz, Samad, Ismi, and Nooreen, 2014).

The review of literature exhibits that there is a necessity to perform research on the implementing verb-noun collocations in written discourse of Iranian EFL learners. However, a quite a few research concentrates on the development and relationship between verb- noun collocations and the productive language, especially writing (AlZahrani, 1998; Hsu, 2002; Zhang, 1993). Bazzaz and Samad (2011) scrutinized the correlation between knowledge of verb noun collocations and their use in writing stories. The subjects in the research were twenty seven PhD Iranian students in a Malaysian university.

In this paper, verb-noun collocations in written discourse of Iranian EFL learners was discussed and the following research question was investigated:

- Is there a significant difference in the correct use of verb-noun collocations in written discourse among Iranian EFL students from one academic year to the next?

\section{Method}

\subsection{Participants}

In this study, there were 212 participants. They were four groups of English major students in an English Department in a university in Tehran in April 2010. They were chosen from the second term of freshman, sophomore, junior, and senior. There were 44 males and 168 females who were between 18-35 at the time of the study. All of them were native speakers of Persian. In the test session, a demographic questionnaire, and a test of writing story were administered to students. The research design employed in this study was a Cross-sectional design and involved the collection of quantitative data. Nevertheless, the chief inadequacy in the Cross-sectional design, which comprises quantitative data, is the lack of the randomised sampling process and the researcher utilises the four intact groups of participants. This shortcoming was overcome by selecting groups through cluster sampling from the second terms of freshman, sophomore, junior, and senior to collect the data.

Krejcie and Morgan's (1970) Table was employed to calculate identical sample sizes in all cases where the researcher changes the $t$ value exploited based on population size and knows the populations. Based on this formula, the population of this study was 480 and the needed sample size of the study was established as two hundred fourteen, but as in most of research, $10 \%$ is added to that number in case some students would not like to participate in the study. Therefore, two hundred thirty five students were selected from four intact groups of male and female students. However, some students withdrew from the experiment in the test session, two hundred and twelve students finished the test. All groups were selected through cluster sampling from the second term of freshman, sophomore, junior, and senior years. Therefore, participants in the present study belonged to four groups which represent each academic level. Group 1 comprised fifty-one students in the second term of their freshmen year. Group 2 included forty-seven students in the second term of their sophomore year, Group 3 consisted of sixty-four students in the second term of their junior year, and Group 4 comprised of fifty students from the second term of their senior year. All respondents were Iranian nationals and spoke Persian as their mother tongue.

\subsection{Instruments}

The instruments of this study were a demographic questionnaire and a test of writing story. In the Writing Test, students wrote six stories in 60 minutes. Each story was based on a picture which was accompanied by three nouns. The respondents were requested to use them. These nouns were intended to elicit the use of verb-noun collocations yet limit the choice of the possible collocations.

A pilot study was conducted in order to ensure that participants could produce verb-noun collocations based on a picture stimulus. A list of topics was given to the respondents. From the list, the participants selected the following six topics: A Picnic, An Accident, A Traffic Jam, Football, At the Restaurant, and Camping (see Appendix VII). An artist then drew a picture based on each topic. These pictures were then given to the participants, and they were asked to write a 250-word composition. The number of verb-noun collocations used in each picture was observed. The three most frequent collocations for every picture were then selected for the Writing and Speaking Tests. 995).

\subsection{Data Analysis}

In order to examine the research question, three statistical measures were used. First, descriptive statistics of all years were used to show the means, the standard deviations, the minimum and the maximum scores of each of the four groups on the Writing Test in which students wrote six stories about a series of six pictures to find the general distribution of the data in the written discourse. Second, to investigate the between-group and within-group differences, a One-Way 
Analysis of Variance, ANOVA, was used. Third, after the results of the One-Way ANOVA were obtained, a post hoc multiple comparison test was performed to determine which means were significantly different from each other.

The results of descriptive statistical analysis show that there is an increase in the students' scores in the written discourse from one year to the next. The summary of the differences among the four academic years for written discourse are depicted in Table 1 below.

Table 1. Summary Table of the Differences among the Four Academic Years in Written Discourse

\begin{tabular}{|c|c|c|c|c|c|c|c|c|}
\hline & \multirow[b]{2}{*}{$\mathrm{N}$} & \multirow[b]{2}{*}{ M } & \multirow[b]{2}{*}{ SD } & \multirow[b]{2}{*}{ SE } & \multicolumn{2}{|c|}{$95 \%$ CIM } & \multirow[b]{2}{*}{ Min } & \multirow[b]{2}{*}{ Max } \\
\hline & & & & & LB & UB & & \\
\hline First & 51 & 12.32 & 1.965 & 0.28 & 11.77 & 12.86 & 10.00 & 17.00 \\
\hline Second & 47 & 13.15 & 1.681 & 0.25 & 12.66 & 13.64 & 10.00 & 16.00 \\
\hline Third & 64 & 13.95 & 1.608 & 0.21 & 13.56 & 14.35 & 11.00 & 17.00 \\
\hline Fourth & 50 & 14.96 & 1.678 & 0.24 & 14.49 & 15.43 & 10.00 & 17.00 \\
\hline Total & 212 & 13.61 & 1.97 & 0.14 & 13.35 & 13.88 & 10.00 & 17.00 \\
\hline
\end{tabular}

Table 1 represents observable differences among the mean scores of the four academic years for writing. The increase in the use of collocations is greater between the first and the fourth years than the second year and the third year. In the Writing Test, the first year students' scores ranged from a minimum of 10 to a maximum of 17 , with a mean score of 12.32. The second level students' scores ranged from 10 to 17 , with a mean of 13.15 indicating a moderate increase from the first to the second academic year. The third year students' scores, however, showed a minimal increase as compared to the first and second year students' scores. That is, their scores ranged between a low of 10 and a high of 16 , with a mean score of 13.96, and a standard deviation of 1.61. The fourth year students' mean scores are higher than the third year students' in the Writing Test with the range of 10 to 17, with a mean score of 14.96 and a standard deviation of 1.68. Looking at the confidence intervals of means for the Writing Test; however, it can be observed that differences are less noticeable, as shown by the standard deviations of $1.97,1.69,1.61$, and 1.68 in written discourse for the first, second, third, and fourth academic year students respectively.

A One-Way Analysis of Variance (ANOVA) was used to measure the use of lexical verb-noun collocations in written discourse. The results of the One-Way ANOVA illustrated that there is variability in the use of verb-noun collocations within each academic year and between the four academic years. Table 2 shows the between-group and within-group variability in the use of verb-noun collocations in written discourse.

Table 2. One-Way Analysis of Variance for the Use of Collocations in Written Discourse

\begin{tabular}{clllll}
\hline Sum of Squares & & df & Mean Square & F & Sig. \\
\hline Between Groups & 194.335 & 3 & 64.778 & 21.603 & 0.0001 \\
Within Groups & 623.717 & & & & \\
Total & 818.052 & 208 & 2.999 & & \\
\hline
\end{tabular}

Note: Difference is significant at the 0.05 level

Table2, clearly shows that there was a significant difference in the proficiency of lexical verb noun collocations both between and within the four academic years, $F(3,208)=20,637$ at the $p<0.0001$ level which is much less than $\alpha \leq$ 0.05 .

After the results of the One-Way ANOVA were acquired a post hoc multiple comparison test was carried out by using Tukey's Honestly Significant Difference (HSD) in order to find out which pairs of means were significantly different from each other. Table 3 shows the multiple comparisons of the means of the four academic years in collocation test performance. 
Table 3. Multiple Comparisons of the Means of the Four Academic Years in the Use of Collocations in Written Discourse

\begin{tabular}{|c|c|c|c|c|c|c|}
\hline \multirow{2}{*}{$\begin{array}{l}\text { (I) } \\
\text { grade }\end{array}$} & \multirow{2}{*}{$\begin{array}{l}(\mathrm{J}) \\
\text { Grade }\end{array}$} & \multirow{2}{*}{$\begin{array}{l}\text { MD } \\
(\mathrm{I}-J)\end{array}$} & \multirow[t]{2}{*}{$\mathrm{SE}$} & \multirow[t]{2}{*}{ Sig. } & \multicolumn{2}{|c|}{$95 \%$ Confidence Interval } \\
\hline & & & & & LB & UB \\
\hline \multirow[t]{4}{*}{ First } & Second & -.84 & .35014 & 0.083 & -1.74 & .0716 \\
\hline & Third & $-1.64^{*}$ & .32504 & 0.0001 & -2.48 & -.797 \\
\hline & Fourth & $-2.65^{*}$ & .34463 & 0.0001 & -3.54 & - \\
\hline & & & & & & 1.753 \\
\hline \multirow[t]{2}{*}{ Second } & Third & -.80 & .33265 & 0.077 & -1.66 & .057 \\
\hline & Fourth & $-1.82^{*}$ & .35181 & 0.0001 & -2.72 & -.899 \\
\hline Third & Fourth & $-1.01^{*}$ & .32684 & 0.12 & -1.85 &.-16 \\
\hline
\end{tabular}

$*$ The mean difference is significant at the 0.05 level.

$\mathrm{LB}=$ lower bound

$\mathrm{UB}=$ upper bound

$\mathrm{MD}=$ mean of difference $(\mathrm{I}-\mathrm{J})$

$\mathrm{SE}=$ standard error

Table 3 above brings to light that the means are significantly different when the first year students' score is compared with the third and fourth years in written discourse at $\mathrm{p}<0.0001$. It shows that students had a significant improvement in their use of collocations in written discourse. For the second year and the third year students, Table 3 shows that there is no difference in written discourse, but there is significant differences between the mean score of second year and the fourth year students in written discourse, as shown by significant level $p=0.077$. There also exists the difference in the mean score of third and fourth years as Table 4-8 represents a significant difference at $\mathrm{p}=0.012$ in written discourse.

Hence, the findings reveal that there are statistical differences in the mean score of the four groups in written discourse. Although there is an improvement in the score from one academic year to the next, these improvements have not been found to be statistically significant. Nevertheless, significant values are obtained when students' scores in an academic year are compared to scores obtained by students two or more years below them. These differences are the most prominent if the first and the fourth years are compared in written discourse. Based on these findings, such statistical differences clearly signify the increase in students' use of collocations.

The results in written discourse are in line with the findings of Zhang (1993) who was the first to examine collocations in EFL/ESL writing. Zhang found that there are correlations between the EFL students' knowledge of collocations, use of collocations (i.e. frequency of accurately produced collocations recorded in student English), and English writing fluency. There are other studies which focus on the development and relationship between collocations and the productive language, especially writing (Al-Zahrani, 1998; Bazzaz \& Samad, 2011; Hsu, 2002, 2007). Al-Zahrani's findings are different from this study because Al-Zahrani did not take into account the use of verb-noun collocations, thus the frequency of verb-noun collocations in the Writing Test was not reported.

\section{Discussion and Pedagogical Implication}

Considering the research question, the results from one-way ANOVA reveal that there are statistical differences in the mean score of the four groups in written discourse. Afterwards, Tukey test was utilised to find out which pairs of means were significantly different from each other. The results indicated additional evidence that there were significant differences both between-groups and within-groups in the use of verb-noun collocations in written discourse. Results discerned that there were significant differences between the first, the third and the fourth academic years, between the second and the fourth academic years, and between the third and the fourth academic years in written discourse. This result in written discourse is consistent with findings of Al-Zahrani (1998), Bazzaz \& Samad (2011), Hsu (2002, 2007), Zhang (1993). These statistical findings revealed that there were differences in Iranian learners' use of verb-noun collocations in written discourse with at least one year interval for the first and the second year students, but for the third and the fourth years every consecutive year. The implication of the research questions is that the ability to correctly use collocations in writing improves as the students' progress through their academic years. Hence, it is not just knowledge of collocations that improves but also the ability to use them as well. Once again, this must be seen within the context of the education system or curriculum which does not explicitly teach collocations, and thus implies a form of learning or acquisition of this ability.

There is also an indication that learners 'acquire' or 'learn' some collocations through some form of developmental process which includes first an incorrect collocation (e.g. shoot the ball) before the correct collocation (kick the ball) is acquired. The findings specify that teachers should focus and teach collocations which are different from the students' mother tongue.

The findings of the study have shown that students increase the knowledge and use of lexical collocations in written discourse through their academic years despite the absence of any formal teaching on collocations. Although this implies that students are able to acquire knowledge of collocations on their own, it does not indicate that formal teaching of collocations should be abandoned. Instead, the findings imply that the students' cognitive processes are actively employed in dealing with collocations when they encounter them outside the classroom. Therefore, the presentation of collocations in the classroom will need to be built on how the students already respond to collocational input outside of the classroom. The role of instruction is to facilitate the acquisition process. This may be achieved by presenting input on collocation that is systematic and well planned. The teacher may want to be selective in presenting verb-noun collocations. This study focused on a few verb-noun collocations which were linguistically different between English and Persian. As previous research in collocations observed that there are a vast number of collocations in English which is calculated to be hundreds of thousands. The teacher may want to focus only on collocations that are linguistically different between the two languages. 


\section{References}

Aghbar. A. A. (1990).Fixed Expressions in Written Texts: Implications for Assessing Writing Sophistication. Paper presented at the meeting of the English Association of Pennsylvania State System Universities.

Aijmer, K., Altenberg, B., \& Svartvik, J. (1991).English corpus linguistics: studies in honour of Jan Svartvik: Longman Publication Group.

Al-Zahrani, M. S. (1998). Knowledge of English lexical collocations among male Saudi college students majoring in English at a Saudi university: Unpublished doctoral dissertation Indiana University of Pennsylvania., Pennsylvania.

Bagherzadeh Hosseini, M. S. \& Akbarian, I. (2007). Language Proficiency and Collocational Competence. The Journal of Asia TEFL, 4(4), 35-58.

Bahns, J., \& Eldaw, M. (1993). Should we teach EFL learners collocations? System, 21(1), 101-114.

Bazzaz, F., \& Samad, A. (2011).The Use of Verb-noun Collocations in Writing Stories among Iranian EFL Learners.English Language Teaching, 4(3), 158-163.

Benson, M. (1985).Lexical combinability. Research on Language \& Social Interaction, 18(1), 3-15.

Benson, M., Benson, E., \& Ilson, R. (1997). The BBI combinatory dictionary of English: a guide to word combinations: John Benjamins Publishing Co.

Biskup, D. (1992). Ll influence on learners' renderings of English collocations: A Polish/German empirical study. In P. L. A. H. Bejoint (Ed.), Vocabulary \& applied linguistics. Houndmills, Basingstoke, Hampshire: Macmillan Academic \& Professional Ltd.

Carter, R. (1998). Vocabulary: Applied linguistic perspectives: Routledge.

Crystal, D. (1992). Introducing linguistics: Penguin English.

Ebrahimi-Bazzaz, F., Samad, A. A., bin Ismail, I. A., Noordin, N., (2012). Measuring Collocational Competence of Iranian Learners by Using C-test. The Iranian EFL Journal, 2, 227- 240.

Ebrahimi-Bazzaz, F., Samad, A. A., bin Ismail, I. A., \& Noordin, N. Verb-Noun Collocation Proficiency and Academic Years. International Journal of Applied Linguistics \& English Literature, 3(1), 152-162

Farghal, M., \& Al-Hamly, M. (2007).Lexical Collocations in EFL Writing. The Journal of Asia TEFL, 4(1), $269-294$.

Firth, J. (1957a).Papers in linguistics 1934-1951. London: Oxford University Press.

Hsu, J.T. \& Chiu, C. (2008). Lexical Collocations and their Relation to Speaking Proficiency of College EFL Learners in Taiwan. Asian EFL Journal.

Kennedy, G. D. (1990). Collocations: Where Grammar and Vocabulary Teaching Meet.In S. Anivan, (Ed.) Language Teaching Methodology for the Nineties (pp. 215-229). RELC, Singapore.

Kjellmer, G. (1991). A mint of phrases.In K. Aijmer and B. Altenberg (Eds.) English Corpus Linguistics (pp. 111-127). Harlow: Longman.

Krejcie, R. V., \& Morgan, D. W. (1970). Determining sample size for research activities. Educ Psychol Meas.

Krishnamurthy, R., \& Kosem, I. (2007).Issues in creating a corpus for EAP pedagogy and research. Journal of English for Academic Purposes, 6(4), 356-373.

Lewis, M. (2000).Teaching collocation: Further developments in the lexical approach. London: Language Teaching Publications.

Liao, E. H. (2010). An investigation of crosslinguistic transfer in EFL learners' phraseology. Alliant International University, San Diego.

Miyakoshi, T. (2009). Investigating ESL learners' lexical collocations: The acquisition of verb+ noun collocations by Japanese learners of English. University of Hawai'i At Manoa.

Nattinger, J. R. (1980). A lexical phrase grammar for ESL.TESOL quarterly, 14(3), 337-344.

Nattinger, J. R., \& DeCarrico, J. S. (1992).Lexical phrases and language teaching. USA: Oxford University Press.

Sinclair, J. (1991). Corpus, concordance, collocation: Oxford University Press.

Wood, D. (2010). Lexical Clusters in an EAP Textbook Corpus. Perspectives on Formulaic Language: Acquisition and Communication, 88 .

Zhang, X. (1993).English collocations and their effect on the writing of native and non-native college freshmen. Indiana 